Article

\title{
Finding Words in the Belly of Sheol: Reading Jonah's Lament in Contexts of Individual and Collective Trauma
}

\author{
L Juliana Claassens (D)
}

Faculty of Theology, Stellenbosch University, Stellenbosch 7600, South Africa; jclaassens@sun.ac.za

\begin{abstract}
By reading Jonah's lament in Jonah 2 through the lens of trauma hermeneutics, this article will try to better understand the words that have been assigned to the main character Jonah, which represent a community's deep sorrow in the aftermath of the unspeakable horrors of warfare. Read as an attempt to ascribe meaning to individual and collective trauma, I propose that Jonah's lament in Jonah 2 taps into the metaphors and images available in the lament tradition of the Book of Psalms. The application of symbolic language in ascribing meaning to traumatic events is particularly significant, and may help us derive new layers of meaning from the words placed into the mouth of the prophet who finds himself in the belly of Sheol.
\end{abstract}

Keywords: trauma hermeneutics; Jonah 2; the book of Jonah; individual and collective trauma

\section{Introduction}

In Pip Williams' bestselling novel, The Dictionary of Lost Words, an officer in the First World War writes to his darling Es from the frontlines. Their life has been built around words-Gareth working at Oxford University Press; Esme being closely involved with the decades-long Oxford Dictionary project in which she has helped define the English language in 12 expansive volumes. Yet Gareth writes "I'm beginning to feel the English language is burdened by this war ... "; how "only a handful of words exist to convey a thousand horrors" (Williams 2021, p. 368).

Even the word "horror" is "war-weary" - "...the word we use when we have no words". Gareth further expresses how the words available to him are "pale and slight against the hulking force of this experience". In his experience, there is no word in the Oxford Dictionary that can capture the stench at the site of war, the "enemy of mud and damp boots", "the itch of fear or the heaviness of dread". As he writes: "You will imagine something awful, but it is worse" (Williams 2021, pp. 368-69).

Nevertheless, Gareth serves as the scribe for a number of his men who cannot help but try to describe what they had experienced during the war, utilizing ordinary words, "assembled into sentences that are grotesque". Even though these words are censored, Gareth meticulously transcribes the uncensored words and sends this uncorrected and truncated version with the owner's name beside it to Esme for safekeeping, for according to Gareth, "I cannot think of [any]one better to honour them than you" (Williams 2021, p. 369).

In some sense, Jonah's lament in Jonah 2, tucked away in the tiny book, which serves as a valiant attempt in making sense of some horrors of their own, could be viewed as a glimpse into a community who, individually and collectively, is seeking to attend to the deep theological and existential questions associated with the suffering wrought by the Babylonian invasion and the aftermath that was the Great War of their time. Typically, the book of Jonah is placed in the postexilic context as responding to the watershed events of the Babylonian invasion and deportation of the people of Judah, followed by the reality of the ongoing subjugation of a colonized people under the Persian Empire. ${ }^{1}$ If one were to accept the argument that Jonah is the product of the Second Temple community, as the 
majority of scholars do, one could then explore the various ways in which the book of Jonah may be viewed as trauma literature, i.e., how the trauma of living in the shadow of one Empire after another takes narrative and poetic shape to mitigate the past and current effects of colonization.

In Jonah 2, one finds that some ordinary, but also rather extraordinary words and images are assembled into sentences that may in their own way be described as "grotesque", but that nevertheless come to us in the hope that we would, as Gareth thought his Es would do, "try to rescue what these boys have said so you can understand them better" (Williams 2021, p. 369).

The meaning of these words is far from clear. Delving through the vast body of work generated by this short book, one is met with a variety of theories concerning whether this psalm in Jonah 2 is original to the book, ${ }^{2}$ has been added later, ${ }^{3}$ or perhaps predates the book in which it has been embedded. ${ }^{4}$ There has been much debate whether this psalm in Jonah 2 fits, or rather does not fit, with its narrative framework. ${ }^{5}$ Of particular interest is how the prophet in whose mouth this lament in Jonah is placed has been regarded. For the most part, scholars have not been kind to Jonah. Serge Frolov (1999, pp. 85-86) offers a comprehensive report of the derogatory and dismissive designations bestowed upon Jonah that include being describing as a "petulant and peevish prophet", being derided for his "narrow outlook and petty hatefulness", as well as for his "colossal egocentrism". 6 In particular, the sincerity of Jonah's words has been questioned with John Holbert (1981, p. 74) claiming that the fish was so disgusted with Jonah's fake piety and hypocrisy that "it is no wonder that immediately after Jonah shouts 'Deliverance belongs to YHWH!' the big fish throws up" (see Sherwood 1998, p. 51; Sharp 2009, pp. 178-79).

By reading Jonah's lament in Jonah 2 through the lens of trauma hermeneutics, this article will try to better understand these words that have been assigned to the main character Jonah, which represent a community's deep sorrow in the aftermath of the unspeakable horrors of warfare. ${ }^{7}$ Read as an attempt to ascribe meaning to individual and collective trauma, I propose that Jonah's lament in Jonah 2 taps into the metaphors and images available in the lament tradition of the Book of Psalms. ${ }^{8}$ The application of symbolic language in ascribing meaning to traumatic events is particularly significant, and may help us derive new layers of meaning from the words placed into the mouth of the prophet who finds himself in the belly of Sheol. By viewing Jonah's lament through the lens of trauma hermeneutics, we are not only presented with a more compassionate reading of the prophet-who probably is one of the most disparaged characters in the Hebrew Bible-but we also may grow in our understanding of how traumatized communities then and since have been trying to find words in the Belly of Sheol. In this regard, the words of Jonah's lament, much like the words from the front, transmitted in Gareth's letter to Esme for safekeeping cited above, are generative as they allow us to contemplate together with Jonah what is worth grieving, both in and outside the proverbial whale.

\section{Finding Words}

"The waters closed in over me;

the deep surrounded me;

weeds were wrapped around my head." (Jon 2:5)

In terms of its narrative placement, Jonah 2 is set up to present the reader with a rare glimpse into the inner world of a prophet hurled into calamity. In the preceding chapter, God's fury is unleashed in a violent storm that causes the ship carrying Jonah to contemplate breaking apart, and the people on board to fear for their lives (Jon 1:4-5). God's violent attack on the ocean in pursuit of the fugitive prophet, couched as an act of war, is intensified in Jon 1:11 when the sea becomes even more turbulent, only subsiding when Jonah, who is held responsible for the raging storm, is thrown overboard (Jon 1:12,15).

During all of this tumult, Jonah does not say much aside from giving brief answers to the captain's inquiry regarding his national identity and religious affiliation (Jon 1:9). 
Even his response after the lot had fallen upon him is sparse, as the prophet, in an act of self-blame, rather placidly accepts his fate (Jon 1:12). In this regard, Boase and Agnew (2016, p. 8) argue in their article on reading the silence of Jonah and his community through the lens of trauma theory that a key feature of trauma is "incommutability", i.e., the inability to find the words to express the effects of trauma on the individual as well as the community as a whole. As they write: "Words fail when the world no longer makes sense. Words fail when meaning has collapsed" (Boase and Agnew 2016, p. 19).9

However, in contrast to his silence throughout most of the book, in Jonah's lament in Jonah 2, the speaker does seem to find words to express his, and as has been suggested, his community's response to the traumatic events represented in this book. Utilizing a first-person narrative technique, the reader is shown something of the inner landscape of the subject as the prophet divulges how he is sinking low, how the waters have gone over his head; how he is surrounded by the deep and entangled in seaweed (Jon 2:5). In Jon 2:6, the speaker is said to continue his descent downwards, sinking into the depths of the sea. His experience of entrapment is graphically illustrated with references to being entangled in seaweed as well as being shut in forever by bars at the roots of the mountains (Limburg 1993, p. 68). ${ }^{10}$ Furthermore, in an attempt to find meaning in the traumatic events that have befallen him and those around him, Jonah-like much of the biblical tradition-identifies God as the source of his suffering: "You cast me into the deep, into the heart of the seas, and the flood surrounded me" (Jon 2:3) (Holbert 1981, p. 71). ${ }^{11}$

In this process of finding words to capture the terrifying display of divine violence that not only traumatized the ship and the passengers on board but also resulted in the near drowning of a man thrown overboard in an attempt to appease the angry deity, Jonah taps into the lament tradition available to him (Pyper 2007, p. 338; Hendel 2019, p. 7). Even though there only is a singular direct correlation with the psalms of lament ("all your breakers and waves swept over $\mathrm{me}^{\prime \prime}$ in Jon 2:4b and Ps 42:8), the language and imagery employed in Jonah 2 are steeped in the motifs and phrases from the lament tradition (see psalms such as Ps 18:4-7; 88:1-2,7,17; Ps 116:3-4,14,17-19; Ps 66:13-14,17,19-20) (Bolin 1997, pp. 112-15; Niebuhr 2014, pp. 126-27). ${ }^{12}$

According to Fiona Black (2019, p. 90), examples of "psalmic depression" have become so widespread during the time in which the book of Jonah saw the light that one may describe it as a type of "lingua franca of exilic times". Indeed, throughout the Psalms of Lament, one finds metaphors and images that denote the physical and emotional anguish of a body in pain (see e.g., Ps 22:14-15's candid description of being "poured out like water", "bones ... out of joint", "heart like wax ... . melted within [one's] breast", a mouth dried up like a potsherd"), as well as the body threatened by external forces, which can be found in the references to animals and enemies surrounding the psalmist (see Ps 22:1314,17-18,21-22) (Black 2019, p. 87). These metaphors that today might well be described in terms of the clinical diagnosis of depression are well suited to helping the traumatized prophet find words to voice his experience of being trapped in the belly of Sheol (Lacocque and Lacocque 1981, p. 88).

Specifically, language associated with the experience of drowning is used in the Psalms to capture the suffering subject's experience of being threatened by whatever forces disturb the wellbeing of the individual or his/her community (McKenzie et al. 2020, p. 102). ${ }^{13}$ This language of drowning fits well with the narrative context in which Jonah's lament is to be found. John Miles (1990, pp. 208-9), arguing for an ironic reading of this text, makes the point that whereas in the Psalms, imagery of waves crashing over the head of the individual is used metaphorically to express the feeling of being overcome by troubles, in Jonah's lament, his "troubles are not like waves washing over his head. His troubles are waves washing over his head" [my emphasis].

Ironic or not, by invoking the language of drowning, sinking, and entering Sheol forever, Jonah is able to exercise a measure of subjectivity, finding the words to express his anguish, desperation, and fear of dying in response to the violent events of the preceding chapter (Black 2019, pp. 86-87). In this regard, Boase and Agnew (2016, p. 17) argue that 
"the outside world" portrayed in Jonah 1 mirrors "the inner state of the central character". Jonah's actions of fleeing, descending into the interior of the ship, and sinking into the sea, which culminates in his sojourn in the belly of the great fish, hence could be read as evidence of Jonah's increasingly state of depression that also aligns with the death wish he repeatedly utters in Jon 4:3,8-9 (Boase and Agnew 2016, p. 6).

However, Jonah's lament does not merely capture the downward journey of an individual sinking ever lower. The lament tradition that informed the prophet's expression of anguish in Jonah 2 also is generative, offering language to the community as a whole, who are struggling to come to terms with the fear of annihilation associated with living in the shadow of one empire after another. The recurrent repetition of traumatic memories, encoded in literature, plays a central role in forging a collective identity through which trauma is socially mediated in terms of a shared suffering (Boase and Agnew 2016, pp. 9, 11). Using a literary strategy of focalization, i.e., telling the story of the community's suffering in terms of Jonah's descent into the depths of the sea and the belly of Sheol, Jonah 2 thus can be said to serve as a space for the community to work through the aftermath of the traumatic wounding they have experienced. ${ }^{14}$

\section{Ascribing Meaning}

"I called to the LORD out of my distress, and he answered me;

out of the belly of Sheol I cried, and you heard my voice." (Jon 2:2)

A further aspect of this process of finding words to name the unnamable pertains to the essential role of symbol and metaphor to ascribe meaning to events that have been responsible for wounding the body and soul. In the letter from The Dictionary of Lost Words with which this article started, Grant bemoans the fact that he is no poet and hence struggles to find the words to express what he and others around him have experienced. He writes that "a poet, could arrange words in a way that ... make an enemy of mud and damp boots and raise your pulse just at the mention of them. A poet might be able to push this word or that to mean something more than what has been ordained by our Dictionary men" (Williams 2021, p. 368).

In terms of the Hebrew Bible, the poets of their time in the prophetic and lyrical traditions played a central role in helping people cope with the aftermath of their own version of the Great War. By tapping into the lament tradition's use of metaphorical language to speak about disaster, death, disease, famine, and war, they could push words further than what they mean as they ascribed meaning to the words gathered together to speak of the trauma caused by the Babylonian Exile and its aftermath. ${ }^{15}$

For instance, the aquatic imagery and specifically the fear of drowning that, in the previous section, was cited in the book of Psalms express the threat of enemy powers and the chaotic forces unleashed by war and destruction is taken to a whole new level in Jonah's lament to capture his experience of suffering, isolation, and despair (Jenson 2008, p. 63; Marcus 1990, p. 124). The metaphor of watery chaos is further explicated in a series of elaborate images denoting Jonah's descent into "'the belly of Sheol', 'the heart of the sea', 'the deep', 'the roots of the mountains', 'the underworld', and 'the pit'," which according to Hendel (2019, p. 5) all are associated with "the realm of chaos and death" (see Kozlova 2021, p. 2; Noegel 2015, pp. 245-49).

Moreover, a further important tradition underlying this process of finding metaphors and symbols to capture individual and collective experiences of trauma in Jonah 2 concerns the application of the well-established Tannîn traditions. ${ }^{16}$ Throughout the ancient Near Eastern traditions, but also in several biblical texts such as Isa 27:1; Jer 51:34; Ps 89:10-11; Job 26:12-13, images of Sea Monsters (see Sea Dragon, Rahab or Leviathan) are invoked to capture all that threatens the wellbeing of the individual and the community. ${ }^{17}$ Such dire situations include the perils of life in the wilderness, being imprisoned, being deathly ill, being caught in a storm at sea, and foremost in the minds of the first recipients of this book, being sent into the Exile, only to afterward experience the hardships of ongoing Persian 
Imperial rule. ${ }^{18}$ For instance, in Jer 51:34, the reference to Nebuchadnezzar swallowing the people demonstrates how Exile has been turned into a wild beast; hence, similar to the Leviathan and the Sea monster, offering visual form to the havoc and great sorrow associated with war and imperial rule (Downs 2009, p. 35; Lasine 2016, p. 252) ${ }^{19}$ As Hendel $(2019$, p. 5) argues, "the hyperbolic imagery of myth" in Jonah's lament has the effect of "rais[ing] the individual's trouble to a matter of cosmic urgency".

Additionally, Ekatarina Kozlova (2021, p. 8) demonstrates how the limits of the metaphorical nature of aquatic imagery associated with Jonah's descent into the depths of the sea are pushed beyond its customary meaning when she represents Jonah's deep-sea drowning in terms of the burial practices of the time. Kozlova interprets, for instance, the assertion, "You cast me into the deep" (Jon 2:3) in the context of Ps 88:7 in which the speaker calls out to God with the words, "you have put me in the lowest pit in dark places, in the depths" (see Ps 22:16). In addition, inanimate objects are personified in terms of this description of Jonah's drowning and burial, with seaweed ensnaring the drowning man, and the Sheol portrayed as a monster with a belly/womb (2021: 1,13-14). In this "a natured theme 'acrostic' of sorrow", Kozlova (2021, pp. 3, 5) argues that Jonah's lament achieves a "totalizing effect in re-counting Jonah's drowning and casts it as an event of cosmic magnitude".

From a trauma perspective, these metaphors and symbols that are introduced to capture the depths of Jonah's despair are significant for another reason. According to trauma theorists, Van Der Kolk and Van Der Hart (1995, p. 171), the metaphorization of individual and collective suffering forms an integral part of the process of mitigating the debilitating effects of trauma on the brain, which has a particular impact on its ability to translate emotion into words (see Van Der Kolk 2014, p. 55; Frechette 2015, pp. 27-28). By activating multiple areas of the brain simultaneously, thus fusing cognition and emotion, the poets are able to ascribe new meaning to the limited words we have for trauma, beyond that which can be found in the lexicon (Claassens 2020, pp. 9-10; see Anker 2009, pp. 55, 58).

However, in the case of the narrative framework in which Jonah 2 is embedded, one also finds the opposite taking place. In addition to the metaphorization of the literal, Jonah's lament is set in what can be described as the literalization of the metaphor, as the symbolic language of sinking down and being engulfed by water and coming close to drowning in the story of Jonah is literalized. In this regard, it is quite interesting to note how "the belly of Sheol" (Jon 2:2), which is the setting for Jonah's lament, is transformed into "the belly of the fish" (Jon 2:1) (Pyper 2007, p. 343). As Yvonne Sherwood (2000, p. 257) poetically captures the book of Jonah's act of "turn[ing] the metaphors into flesh-his Pit/Sheol comes with matching blubber and fins". ${ }^{20}$ In terms of Jonah being swallowed by a big fish, one may argue that the fears associated with all that put individuals and communities into jeopardy have taken on tangible form.

\section{Confusing Categories}

"As my life was ebbing away, I remembered the LORD;

and my prayer came to you, into your holy temple." (Jon 2:7)

This link between symbol and trauma may offer also new insight into one of the enduring controversies surrounding the genre of Jonah 2. Scholars have been confounded by the manifold inconsistencies in this chapter regarding how Jonah can call out for deliverance and speak of drowning when the sea already has calmed down (Jon 2:3, see Jon 1:15), or how he can speak of being in the temple while still being in the innards of the fish (Jon 2:7,10) (Pyper 2007, p. 337; Bolin 1997, p. 101)?21 Ronald Hendel (2019, p. 1) rightly observes that the speaker's claim to be in the temple in Jerusalem "complicates the temporal and spatial dynamics" (see Mikhail Bakhtin's notion of the chronotope) ${ }^{22}$ of Jonah's lament when he sings a song of thanksgiving while still very much in "the belly of the beast". 
On the one hand, this literary disorder may be intentional, mirroring something of the turbulence experienced by a traumatized people. With regard to the book of Jeremiah, Kathleen O'Connor (2011, pp. 126-27) argues that Jeremiah's "bewildering array of voices, themes, metaphors, genres, and its lack of narrative order" "reflects the massive disorder that produced the book in the first place". Similarly, this undoing of categories of time and space receives new significance when considered in the context of contemporary trauma narratives which have been shown to employ the subversion of categories of time, space, and character to convey something of the utterly confusing nature of the traumatic experience. Elsewhere, I have drawn on the work of Roland Granofsky who has outlined the use of literary symbolism in contemporary trauma specifically pertaining to how "the trauma novel deconstructs categories such as time and space, so mirroring the disorienting effects of trauma on the human psyche" (Claassens Forthcoming). In conversation with Granofsky's analysis of Martin Amis' 1991 novel, Time's Arrow (Ames 1991), as a powerful example of how time and space are "wrenched out of alignment" by communal trauma, I identify instances in the book of Jonah in which categories of time, space, and character are deconstructed to, in symbolic terms, represent a traumatic past in narrative form. Concerning Jonah 2, I propose that one could argue that, as in the case of a symbolic trauma narrative, time and space similarly may seem out of joint. However, viewed in terms of trauma hermeneutics, and particularly given the intricate connection between symbol and trauma, this spatial and temporal confusion could be viewed as a narrative strategy intent on ascribing meaning to world-turned-upside-down events.

Additionally, Hendel (2019, p. 1) proposes that Jonah's lament translates mythic categories into "a poetic narrative" that "refocuse[s]" the myth "from the cosmos to the microcosm and from primeval to present time". For Hendel (2019, pp. 4, 6), this appropriation of the mythic categories of primeval conflict in which God is victorious is "a resource when chaos reasserts itself", encapsulating God's ability to restore order with the image of the cosmic center at the temple in Jerusalem. Viewed in this way, the notion of the belly of the Sheol/whale being transformed into a temple takes on new significance as it transforms the potentially debilitating experience of overwhelming chaos as represented in the raging waters and the sea monster (Leviathan/Rahab) into a space not to be feared, but in a place of worship where Jonah is able to reach out to his God. ${ }^{23}$

In terms of this interpretation of the sea monster, which epitomizes the forces of chaos and disruption, the terrifying Leviathan that has been God's opponent throughout the ancient traditions is reduced to merely a big fish that quite ironically becomes the vehicle of Jonah's deliverance. ${ }^{24}$ The fears of the prophet, representing the fears of his community, in this text are thus turned into the space of his transformation. As the community, in the letter of the prophet Jeremiah to the exilic community (Jeremiah 29), had to hear that they could and should live amid exile, so Jonah's presence in "the belly of the beast" serves in a sense as a type of "comic deflation:" as a means to undo the life-destroying force of exile, thus wrenching life back while still engulfed by the chaos monster that, in this story, proves to be only a big fish! (Cary 2008, pp. 75-76; Lacocque and Lacocque 1981, p. 79).

\section{Joining Jonah in and outside of the Whale}

Reading Jonah's lament through the lens of trauma hermeneutics offers us insight into the innovative ways in which individuals and a community a world away sought to make sense of the forces of chaos that overwhelmed every facet of their lives. Much as the poets of Jonah 2 tapped into the ancient Near Eastern traditions and lyrical traditions of the Hebrew Bible available to them, so Jonah's lament can be said to be generative as well, offering future communities, who may also feel that they are sinking, the language and impetus to consider their own contexts of trauma. ${ }^{25}$

Scholars such as Thomas Bolin (1997, pp. 13-63), Yvonne Sherwood (2000), and most recently Lena-Sofia Tiemeyer, in her new Wiley Blackwell Bible Commentary on the reception history of Jonah (Tiemeyer 2021), as well as Amy Ericson in the Eerdmans Illuminations Commentary Series (Erickson 2021), have engaged in the epic task of compiling the wealth 
of traditions generated by Jonah's lament in the Judean-Christian tradition. Their compilations on the reception history of the book of Jonah demonstrate just how deeply ingrained Jonah's lament from the belly of the whale/Sheol is in the western consciousness, finding expression in art, music, and literature. What many of these interpretations have in common is that they seek to understand their own situation within the contours of the words and images contained in this book, with the community generating interpretations, applications, and explanations of their own to voice that which is beyond comprehension. ${ }^{26}$

Some of these interpretations are more fanciful and absurd than others (e.g., the delightful rabbinic interpretation regarding a pregnant fish), ${ }^{27}$ telling us perhaps more about the community producing these interpretations than the original composition itself. Two of these interconnected interpretations offer an interesting perspective on contemporary individuals" efforts in dealing with the "thousand horrors" of war and imperial rule that continues the conversation on Jonah's lament in the belly of the whale. In an opinion piece, "Inside the Whale" (Orwell [1940] 1979), George Orwell critiques-amongst others-the work of the author, Henry Miller, who in terms of the classic poem by Aldous Huxley is drawn to the idea of Jonah hiding away in the belly of the whale-something which Orwell describes as being "cosset[ed] ... in an adult womb" with "a yard of blubber between yourself and reality" (Orwell [1940] 1979, pp. 42-43, cited in Sherwood 2000, p. 139). ${ }^{28}$ According to Sherwood (2000, pp. 139-40), Orwell's image of Jonah in the whale hence serves as a symbol of an "a-political quietism", of hiding away amidst the atrocities wrought by war, including the concentration camps during the holocaust, nuclear bombs, as well as a range of other references to the threat and the reality of terror under dictators such as Hitler and Stalin. Orwell's use of the figure of Jonah-inside-the-whale is perhaps reminiscent also of how Lacocque and Lacocque (1981, p. 80) have characterized Jonah's acts of fleeing away, going down into the boat, and further down into yet another enclosure of the innards of a big fish, as a Jonah-complex that has come to be known as a well-known psychological category to capture the tendency to evade responsibility. ${ }^{29}$

In conversation with Orwell, Salman Rushdie would pick up on this metaphor, used by Orwell, many years later when he argues in an essay called, "Outside the Whale" (Rushdie 1984, pp. 92, 101, cited in Sherwood 2000, p. 140), that the world in which he is writing is "whaleless", hence with no "quiet corners in which to escape from history from hullabaloo, from terrible unquiet fuss". In Sherwood's discussion of these interpreters' application of the Jonah trope, she argues that Jonah is passed on from one author to the other, serving as "a symbol of a-political introversion, and his whale becomes, variously, a cosseting womb for the hard-of-living, and a glass-walled vessel where the most courageous of life's refugees can at least look out" (Sherwood 2000, p. 140).

These examples from the reception history of Jonah attest to the fact that, as Hendel $(2019$, p. 6) rightly has argued, "the psalm of Jonah is reusable by other speakers in other [dire] straits". Orwell and Rushdie's appropriation of Jonah in and outside of the whale have commonality with the original lament of Jonah, in that both these interpretations continue to appropriate metaphorical language to ascribe meaning to trauma-inducing events in their respective contexts. One could argue that both Orwell and Rushdie consider the outside forces of chaos in terms of the Taanîm, the Leviathans, and the Rahabs of their time that threatens to swallow individuals and communities. ${ }^{30}$ In this regard, Hendel $(2019$, p. 1) writes how in "the afterlife of the psalm", the various signifiers are expanded and remythologized to capture "new concepts of apocalyptic trouble and rescue as its chronotype expands to new configurations of time and space" ${ }^{31}$ It is significant, though, that both the interpretations of Orwell and Rushdie seem to suggest that it would be good for the proverbial Jonah to exit the whale and face the ills associated with the ongoing abuse of power by the new imperial forces that, just as it did for the original community represented by Jonah's lament, threatens the wellbeing of individuals and communities in their respective contexts. 


\section{Conclusions}

In this article, we have seen how reading Jonah 2 through the lens of trauma hermeneutics and the words that come to us from a distant past may help readers encounter a wounded individual, and his wounded community, who has lived through some greatly traumatizing experiences. ${ }^{32}$ With these words that inform Jonah's lament, the speaker is validated in his suffering-as Black (2019, p. 86) says so well in terms of the subject in the Psalms of Lament: "the questioner persists". This portrait of Jonah as a persistent questioner continues in the rest of the book as the traumatized prophet finds himself in Jonah 3-4 outside the city of Nineveh, once more finding the words to hold God, whom he deems responsible for the suffering that has been bestowed upon him and the community, accountable (Jon 4:2,8-9). ${ }^{33}$

Perhaps Jonah in the belly of Sheol/the big fish is more engaged than his critics, who have named a psychological complex and an a-political stance after him, would give him credit for? After all, in his lament in Jonah 2 that aligns with the lament tradition in the Lyrical Literature of the Hebrew Bible (Lamentations, Psalms of Lament), as in the Prophetic books (see the confessions and prayers of Jeremiah) and the Wisdom tradition (Job; Ecclesiastes), Jonah does take on the well-established dogma of theodicy when he challenges the notion that God is responsible for suffering. ${ }^{34}$ Moreover, postcolonial scholars who have come out in defense of Jonah have compellingly shown how Jonah challenges the superpowers of the day-more than once, actually, if one takes seriously the conflation of Assyria-Babylon-Persia at work in the capital city of Nineveh that forms the setting of Jonah's dissent. ${ }^{35}$

By joining Jonah in lament both in and outside the whale, a whole new generation of readers are able to reflect on the exceedingly precarious situations in which they find themselves, with ever-emerging monsters that seek to destroy or undo that what makes life worth living. Knowing this, we might be less inclined to point a disapproving finger at Jonah, who sought to flee to the farthest ends of the universe to escape from the ongoing effects of the empire that remains. Instead, we are prompted by Jonah's Lament in the Belly of Sheol to ourselves find words to name those life-denying forces, ascribing meaning by using similarly inventive symbolic language to express the inexpressible as exemplified in Jonah 2. Inspired by postcolonial interpreters, for Jonah and his readers with him, as Orwell and Rushdie so imaginatively have suggested, to exit the whale is a powerful symbol of holding accountable whatever powers are represented by the Nineveh of the day.

Funding: This research received no external funding.

Conflicts of Interest: The author declares no conflict of interest.

\section{Notes}

A long list of scholars, based on linguistic features, unique vocabulary found in Late Biblical Hebrew, as well as source-critical arguments make a compelling case for a postexilic dating for the book of Jonah. See e.g., (Ben Zvi 2003, pp. 7-9; Boase and Agnew 2016, p. 7; Noegel 2015, p. 243; Jenson 2008, pp. 29-30; Levine 2000, p. 71; Kim 2007, p. 520; Alter 2015, pp. 185-87; Limburg 1993, pp. 29-31; Erickson 2021, pp. 22-30). For a comprehensive list of all the scholars who support a postexilic dating for the book of Jonah see (Ryu 2009, pp. 196-97 fn 3). Riley (2012, p. 118) formulates this position, which also serves as the point of departure of this article, well: " ... [R]ecent publications argue that the book was most likely produced in the Persian period of mid-sixth to mid-fourth century B.C.E., long after the Assyrian empire had ceased to exist. Yet, if such a dating is accepted, one must recognize the long history of imperial influences on Judah and on those who would have produced the work. As Lowell Handy argues for his dating of the book to the Persian period, "It provides a time when ... there is an empire that can be compared to and taken as a continuation of the Assyrian world empire, and the events of both Assyria's demise and Babylonian incorporation into the Persian Empire were well in the past and yet still of interest to the intellectual circles". My point here is not so much to argue for an acceptance of a particular dating of the book, but rather to show that, no matter at what point one places the work, the influence of larger empires such as Assyria, Babylon, and Persia would have shaped the construction of the book and the import of its message". 
2 See e.g., George M. Landes' (1967, pp. 3-31) seminal argument regarding the integrity of the Jonah psalm that is built on identifying close connections to the narrative structure of the book of Jonah as a whole. See Bolin (1997, pp. 99-101) for a succinct description of the authors building on Landes' position.

3 For a review of the various positions see Sasson (1990, p. 205). For a new proposal regarding the various compositional layers of the book of Jonah, and particularly the redactional activity associated with the poem in Jonah 2, see McKenzie et al. (2020, 97ff). For a good overview of the various positions associated with "The Psalm Came First" positions, see Pyper (2007, pp. 339-42). Pyper builds on this idea, suggesting that the Psalm may have served as a source for the narrative section when he argues that "the book of Jonah is a kind of midrash derived by way of the Jonah-psalm from $2 \mathrm{Kgs} \mathrm{14.23-29.} \mathrm{In} \mathrm{terms} \mathrm{of} \mathrm{a} \mathrm{delightful} \mathrm{use}$ of metaphor, Pyper (2007, p. 339) proposes that "the Jonah-psalm swallows the prophet Jonah mentioned in 2 Kgs 14.25 and regurgitates him in a critique of a theology of retribution and a narrow view of Israel's mission".

See Benckhuysen's (2012, pp. 5-20) discussion of the various inconsistencies between the psalm in Jonah 2 and the rest of the prose narratives that generated a wide range of proposals of how to solve this interpretative dilemma.

6 This line of interpretation relates to the theme of universalism that often is argued to be central to the book of Jonah's portrayal of a God whose compassion extends beyond the people of Israel to the non-Israelite sailors and even Israel's worst enemies, the people of Nineveh (see e.g., Limburg 1993, pp. 34-35; Cary 2008, pp. 132, 159 and others). However, several scholars-including Sherwood (2000, pp. 53-54), Bolin (1997, pp. 58-60), Jenson (2008, pp. 35-36), and Erickson (2021, pp. 3-5) - have argued against an uncritical acceptance of such a theme of universalism, warning of the danger of anti-Semitic interpretations embedded in what Bolin (2009, p. 2) describes as "a Christian caricature of post-exilic Judaism informed by a deeply ingrained anti-Jewish reading" of the book of Jonah. Postcolonial interpreters have also challenged this line of interpretation. E.g., Ryu (2009, p. 199) contends that "embedded in this inclusivity of universalism is a working system of exclusivity which makes the voice of the weak and the marginalized disappear. That which lies behind the claim of universalism might well be the dominance of First-World interpreters".

7 Boase and Agnew's (2016, pp. 14, 19) article on reading the book of Jonah through the lens of trauma hermeneutics focuses specifically on how Jonah's silence at the end of the book points to the ongoing collapse of meaning that has been shown to be a symptom of trauma. I propose that, in contrast to Jonah's silence in Jonah 4, the lament assigned to the prophet in Jonah 2 serves as a way to break the silence, moving the traumatized individual(s) into speech.

8 See the argument by Yates (2016, p. 231). I propose in this article that, similar to many of the Psalms of Lament that already contain elements of thanksgiving even before salvation has occurred, the references to thanksgiving in Jonah 2 are also intrinsically connected to the Lament Psalm that forms the focus of this study. See Bolin (1997, pp. 101-2). For an overview of attempts to reconcile the Psalm of Lament with the Psalm of Thanksgiving see Benckhuysen (2012, pp. 9-14), which also includes a reference to the oft-cited article by Landes (1967, pp. 15-16) that has argued for two distinct psalms in this chapter.

Boase and Agnew (2016, p. 19) read the silence at the end of the book as symptomatic of communal trauma and hence not to be taken as grounds for condemnation and judgment.

As John A. Miles (1990, p. 209) writes "The references in v. 7 to the base of the mountains and the bars of Earth are no less watery than the others, for the foundation of the cosmic mountain is the cosmic river which also bars or limits the earth". See O'Connor (2014, p. 217) who describes self-blame as a "survival strategy" for many individuals facing trauma.

However, as Bolin (1997, pp. 113-14) has rightly pointed out, Jonah's psalm is "more than just an elaborate patchwork of quotations/motifs/segments drawn from widely divergent areas of the Psalter and representative repertoire of the biblical poets". Rather, citing the work of Julius Bewer, Bolin $(1997$, p. 113) argues that Jonah's author was "steeped in the religious language of the post-exilic community". See Kozlova (2021, p. 6) who outlines the distinct role of the text's "liquid vocabulary" to represent "Jonah's deep-sea drowning". Laurie Vickroy (2015, Location 578/582) describes the narrative technique of "focalization" as the process by which a narrator using "first-person narration" employs the inner-world of a character as the "perceptual viewpoint or angle" from which a narrative is told. See Irmtraud Fischer's (2018, pp. 305-15) reading of Jonah through the lens of trauma.

See Noegel's (2015, pp. 242-55) in-depth discussion of the role of the Tannîn traditions in the book of Jonah.

Hendel (2019, p. 4) describes these "myths of the conflict of order and chaos" that informed "Israel's cultural context", including: "the Canaanite myth of Baal's conflicts with Sea [Yamm] and Death [Mot]; the Mesopotamian myth of Marduk's conflict with Sea [Tiamat]; and biblical accounts of Yahweh's conflicts with Sea [yām] and other oceanic monsters (Tannîn, Leviathan, etc.)". See Downs (2009, pp. 35-36); Kelsey (2020, p. 129); Cary (2008, p. 75); Lacocque and Lacocque (1981, p. 78). A contrary argument is found in Landes (1967, p. 13), who maintains that the author of Jonah deliberately uses the term "fish" to avoid reference to the sea monsters. See Tiemeyer (2017a, p. 50) who argues that the LXX does understand Jonah's fish as "some kind of monster ... but "nothing as monstrous as the Tannin or the Leviathan". Nevertheless, as will be argued in this article, in correspondence with the numerous authors who do see a continuation with the Chaos monsters' motif, this usage might well be ironic and rhetorically significant. 
See e.g., Psalm 107, which according to Hendel (2019, p. 5), offers "a poetic catalogue of comparable circumstances" which compelled people to cry out to God for deliverance ( $\mathrm{v} 6$ ). For an exposition on how the experience of exile informs Jonah's lament, see Downs (2009, p. 34) and Lacocque and Lacocque (1981, p. 79).

It is significant that the root "to swallow" that is used in Jon 2:1 to describe the big fish's act of ingesting the drowning Jonah, elsewhere in the Hebrew Bible is used in the context of death, war, and military defeat, etc. For instance, in 2 Sam 17:16, David and his people are said to "be swallowed up" (see "to swallow up the Lord's inheritance" in 2 Sam 20:19-20. See Hos. 8:7-8; Lam. 2:2,5,16; Ps 21:9, 124:3). In Exod. 15:12; Num. 16:30, 32, 34; 26:10; Ps 69:16, 106:17; Prov 1:12, death (Sheol/the deep) is shown as opening its mouth and swallowing its victims (Wildberger 1997, p. 532; Erickson 2021, p. 291). In contrast, see how God is shown to conquer death when God in Isa 25:7-8 swallows the shrouds representing death.

Pyper (2007, p. 347) describes the difference between his and Sherwood's undertaking as follows: "The difference here is that Sherwood sees a more general metaphorical extravagance and what she calls an 'over-actualisation of the tradition' in the book, which affects the psalm as well as the prose, while I am arguing for a specific act of (over-)actualisation as a reading strategy by the Jonah-writer".

Landes (1967, pp. 15-16), and other scholars after him, proposed a two separate prayers solution, i.e., that this psalm contains references to a past lament in the context of a prayer for thanksgiving.

According to Mikhail Bakhtin (1981, p. 84), "chronotype" relates to the way in which time and space relate to each other, specifically pertaining to "[ $\mathrm{t}]$ he intrinsic connectedness of temporal and spatial relationships that are artistically expressed in literature". As he argues: "Time, as it were, thickens, takes on flesh, becomes artistically visible; likewise, space becomes charged and responsive to the movements of time, plot and history".

See Lacocque and Lacocque's (1981, p. 77) reference to the fish as the place of theophany. See a delightful interpretation from Pirke de Rabbi Eliezer cited by Sherwood $(1998$, p. 65) in which "Jonah finds himself in a synagogue, a place of study, illuminated by eye-windows and by a pearl that hangs from the stomach roof. The transformed belly is also a place of transformation .... in which the prophet ... . changes his identity and becomes a mythological superhero". Instead of chasing after the Ninevites, Jonah vows to catch the Leviathan, which in the rabbinic tradition is to be served at "the messianic feast of the righteous" (see Tiemeyer 2017a, p. 52).

Pyper (2007, p. 346) points to the irony of the big fish in Jonah 2 in terms of Ps 104:26 in which the Leviathan, which throughout the Ancient Near Eastern traditions has been the primeval opponent of God, is reduced to God's bath toy. See Sharp (2009, p. 179) who argues that "The 'rescue' of the drowning Jonah by the fish is, on one level, what it seems. But on a deeper level, it constitutes an ironic feint toward a view of deliverance that becomes increasingly untenable as three days pass and the reader is given the opportunity to consider Jonah's fishy intragastric imprisonment at more length". See Tiemeyer's (2017a, pp. 47-70) in-depth discussion on the way in which Jonah's fish increasingly has come to be viewed as a monster in early Jewish and Christian reception history.

See Black's (2019, pp. 90-91) argument that the language of lament is generative as the expressions that draw one's attention to the body in pain, help "make a case to the public that there is something to be lamented". To open up "the biblical colonial narrative and insert or explore the voices of dissent" may also help future captives to lament as well.

Citing George Orwell's reference to the "hold [of] the Jonah myth ... upon our imaginations", Lasine (2016, p. 251) argues that given the rich reception history in both words and images, as well as also in children's literature and popular culture, one cannot deny the enduring impact of this story.

Bolin (1997, p. 107) cites a delightful interpretation from the Midrash Jonah that sought to explain the sex change the male fish that swallowed Jonah (Jon 2:1) underwent to become a female fish vomiting out the prophet in Jon 2:9. As Bolin recounts the midrash's explanation: "God saw that Jonah was comfortable inside the roomy confines of the male fish. Therefore he appointed a second fish to swallow Jonah, a female, pregnant with 365,000 of her young. The male fish spat Jonah into the female's mount. In his new surroundings, Jonah was so cramped and miserable that he prayed for forgiveness and release. God relented, had Jonah spat back into a male fish, and then vomited upon shore". See Tiemeyer (2017b, pp. 314-15).

See Lacocque and Lacocque $(1981$, p. 80$)$ who develop the symbolic connotations of the womb as offering a unique blend of "protection and isolation".

29 The designation of a "Jonah Complex" goes back to Abraham Mazlow, who has argued: "So often we run away from the responsibilities dictated (or rather suggested) by nature, by fate, even sometimes by accident, just as Jonah tried-in vain—to run away from his fate". This is cited in Lasine (2016, p. 248), who offers an excellent overview of the various permutations of the so-called Jonah Complex in both the world of psychology as well as in biblical scholarship.

See Lasine (2016, p. 252) who makes a connection between fairy tales such as Little Red Riding Hood and Pinocchio which also center around the motif of the "child" being swallowed whole by a monstrous shark or wolf, but who nevertheless survive amidst the belly of the beast.

31 Hendel (2019, p. 8) argues that "the chronotope of Jonah's psalm expands to include the marvelous events of the end time", including "the cosmic battle", "Jesus and other messiahs", "the resurrection of the dead", "conclud[ing] with a joyful afterlife in the New Jerusalem". Moreover, Hendel $(2019$, p. 6) proposes that "the elements of thanksgiving, which are incorporated in 
Jonah's lament, ultimately imply that God will also be "receptive to future cries", and ultimately victorious in the cosmic battle against chaos"'.

32 Boase and Agnew (2016, p. 6) highlight the importance of reading with compassion, i.e., being sensitive to the deep emotional wounds created by the experience of trauma, and hence to read "with and not against Jonah and his community".

See how this notion of lament as resistance is picked by postcolonial interpreters e.g., (Havea 2013, pp. 44-55; 2016, pp. 94-108; Ryu 2009, pp. 195-218).

As Carey Walsh (2015, pp. 265-66) has argued, Jonah serves as "a cipher to mediate the community's pained questioning" after the exile, asking YHWH such questions as: "Where were you? Are you reliable? Does repentance matter?".

See Jione Havea's (2013, pp. 50-52) defense of Jonah's anger with the prophet challenging both God (and the colonizer) on behalf of people, such as the ones of his context of Oceania, who have suffered under the yoke of colonization.

\section{References}

Alter, Robert. 2015. Strong as Death Is Love: The Song of Songs, Ruth, Esther, Jonah, and Daniel, a Translation with Commentary. New York: W.W. Norton \& Company.

Ames, Martin. 1991. Time's Arrow. New York: Vintage International.

Anker, Johan. 2009. Metaphors of Pain: The Use of Metaphors in Trauma Narrative with Reference to Fugitive Pieces. Literator 30: 49-68. [CrossRef]

Bakhtin, Mikhail M. 1981. Forms of Time and Chronotope in the Novel. In The Dialogic Imagination: Four Essays. Edited by Caryl Emerson and Michael Holquist. Translated by Michael Holquist. Austin: University of Texas Press, pp. 84-258.

Ben Zvi, Ehud. 2003. The Signs of Jonah: Reading and Rereading in Ancient Yehud. New York: Bloomsbury T \& T Clark.

Benckhuysen, Amanda W. 2012. Revisiting the Psalm of Jonah. CTJ 47: 5-31.

Black, Fiona. 2019. Public Suffering? Affect and the Lament Psalms as Forms of Private-Political Depression. In Reading with Feeling, Affect Theory and the Bible. Semeia Studies. Edited by Fiona C. Black and Jennifer L. Koosed. Atlanta: SBL, pp. 71-94.

Boase, Elizabeth, and Sarah Agnew. 2016. "Whispered in the Sound of Silence": Traumatizing the Book of Jonah. The Bible E Critical Theory 12: 4-22.

Bolin, Thomas M. 1997. Freedom beyond Forgiveness: The Book of Jonah Re-Examined. Sheffield: Sheffield Academic Press.

Bolin, Thomas M. 2009. Eternal Delight And Deliciousness: The Book of Jonah After Ten Years. The Journal of Hebrew Scriptures 9: 2-11. [CrossRef]

Cary, Phillip. 2008. Jonah. Brazos Theological Commentary on the Bible. Grand Rapids: Brazos Press.

Claassens, L. Juliana. 2020. Writing and Reading to Survive: Biblical and Contemporary Trauma Narratives in Conversation. Sheffield: Sheffield Phoenix Press.

Claassens, L. Juliana. Forthcoming. Facing the Colonizer that Remains: Jonah as a Symbolic Trauma Narrative. CBQ.

Downs, David J. 2009. The Specter of Exile in the Story of Jonah. Horizons in Biblical Theology 31: 27-44. [CrossRef]

Erickson, Amy. 2021. Jonah: Introduction and Commentary. Illuminations. Grand Rapids: William B. Eerdmans.

Fischer, Irmtraud. 2018. Alles andere als zum Lachen: Das Jonabuch als Anleitung zur Traumatisierungsbewältigung. In The Books of the Twelve Prophets. Bibliotheca Ephemeridum Theologicarum Lovaniensium 295. Edited by Heinz-Josef Fabry. Leuven: Peeters, pp. 305-15.

Frechette, Christopher. 2015. The Old Testament as Controlled Substance: How Insights from Trauma Studies Reveal Healing Capacities in Potentially Harmful Texts. Interpretation 69: 20-34. [CrossRef]

Frolov, Serge. 1999. Returning the Ticket: God and His Prophet in the Book of Jonah. JSOT 86: 85-105. [CrossRef]

Havea, Jione. 2013. Adjusting Jonah. International Review of Mission 102: 44-55. [CrossRef]

Havea, Jione. 2016. Sitting Jonah with Job: Resailing Intertextuality. Bible E Critical Theory 12: 94-108.

Hendel, Ronald. 2019. Myth and Mimesis in the Psalm of Jonah. In Psalms in/on Jerusalem. Edited by Ilana Pardes and Ophir Münz-Manor. Berlin: De Gruyter, pp. 1-10. [CrossRef]

Holbert, John C. 1981. “Deliverance Belongs To Yahweh!”: Satire in the Book of Jonah. JSOT 21: 59-81.

Jenson, Philip P. 2008. Obadiah, Jonah, Micah: A Theological Commentary. New York: T \& T Clark.

Kelsey, Marian. 2020. The Book of Jonah and the Theme of Exile. JSOT 45: 128-40. [CrossRef]

Kim, Hyun Chul Paul. 2007. Jonah Read Intertextually. JBL 126: 497-528. [CrossRef]

Kozlova, Ekaterina E. 2021. Jonah 2: A Death Liturgy for the Doomed Prophet. Journal of Hebrew Scriptures 20: 1-21. [CrossRef]

Lacocque, Andre, and Pierre-Emmanuel Lacocque. 1981. The Jonah Complex. Louisville: John Knox Press.

Landes, George M. 1967. The Kerygma of the Book of Jonah: The Contextual Interpretation of the Jonah Psalm. Interpretation $21: 3-31$. [CrossRef]

Lasine, Stuart. 2016. Jonah's Complexes and Our Own: Psychology and the Interpretation of the Book of Jonah. JSOT 41: 237-60. [CrossRef]

Levine, Etan. 2000. Reopening the Case of Jonah vs. God. In Heaven and Earth, Law and Love. Beihefte zur Zeitschrift für die Alttestamentliche Wissenschaft. Berlin: Walter de Gruyter, pp. 67-97.

Limburg, James. 1993. Jonah: A Commentary. The Old Testament Library. Louisville: Westminster John Knox.

Marcus, David. 1990. From Balaam to Jonah: Anti-Prophetic Satire in the Hebrew Bible. BJS 301. Atlanta: Scholars. 
McKenzie, Steven L., Rihannon Graybill, and John Kalter. 2020. Underwater Archaeology: The Compositional Layers of the Book of Jonah. Vetus Testamentum 70: 83-103. [CrossRef]

Miles, John A. 1990. Laughing at the Bible: Jonah as Parody. In On Humour and the Comic in the Hebrew Bible. BLS 23. Edited by Athalya Brenner. Sheffield: Almond Press, pp. 203-16.

Niebuhr, Karl-Wilhelm. 2014. Psalms Outside the Biblical Psalms Collection-The Example of Jonah. In Singing the Songs of the Lord in Foreign Lands: Psalms in Contemporary Lutheran Interpretation. Edited by Kenneth Mtata, Karl-Wilhelm Niebuhr and Miriam Rose. Leipzig: Evangelische Verlangsanstalt GmbH, pp. 121-38.

Noegel, Scott B. 2015. Jonah and Leviathan: Inner-Biblical Allusions and the Problem with Dragons. Hen 37: 236-60.

O'Connor, Kathleen M. 2011. Jeremiah: Pain and Promise. Minneapolis: Fortress Press.

O'Connor, Kathleen M. 2014. How Trauma Studies Can Contribute to Old Testament Studies. In Trauma and Traumatization in Individual and Collective Dimensions: Insights from Biblical Studies and Beyond. Edited by Eve-Marie Becker, Jan Dochhorn and Else Holt. Göttingen: Vandenhoeck and Ruprecht, pp. 210-22.

Orwell, George. 1979. Inside the Whale. In Inside the Whale and Other Essays. Harmandsworth. Middlesex: Penguin, pp. 9-50. First published 1940.

Pyper, Hugh S. 2007. Swallowed By a Song: Jonah and the Jonah-Psalm Through the Looking-Glass. In Reflection and Refraction: Studies in Biblical Historiography in Honour of A. Graeme Auld. Edited by Robert Rezetko, Timothy H. Lim and W. Brian Aucker. Leiden: Brill, pp. 337-58.

Riley, Stephen Patrick. 2012. When the Empire Does Not Strike Back: Reading Jonah in Light of Empire. Wesleyan Theological Journal 47: 116-26.

Rushdie, Salman. 1984. Outside the Whale. Granta. Available online: https:/ /granta.com/outside-the-whale/ (accessed on 14 January 2022).

Ryu, Chesung Justin. 2009. Silence as Resistance: A Postcolonial Reading of the Silence of Jonah in Jonah 4.1-11. JSOT 34: 195-218. [CrossRef]

Sasson, Jack M. 1990. Jonah: A New Translation with Introduction, Commentary, and Interpretations. Anchor Bible 24B. New York: Doubleday.

Sharp, Carolyn J. 2009. Irony and Meaning in the Hebrew Bible. Bloomington: Indiana University Press.

Sherwood, Yvonne. 1998. Cross-Currents in the Book of Jonah: Some Jewish and Cultural Midrashim on a Traditional Text. BibInt 6: 49-79. [CrossRef]

Sherwood, Yvonne. 2000. A Biblical Text and Its Afterlives The Survival of Jonah in Western Culture. Cambridge: Cambridge University Press.

Tiemeyer, Lena Sofia. 2017a. Jonah and His Fish: The Monstrification of God's Servant in Early Jewish and Christian Reception History. In Fallen Animals: Art, Religion, Literature. Edited by Zohar Hadromi-Allouche. Lanham: Lexington Books, pp. 47-70.

Tiemeyer, Lena-Sofia. 2017b. A New Look at the Biological Sex/Grammatical Gender of Jonah's Fish. Vetus Testamentum 67: 307-23. [CrossRef]

Tiemeyer, Lena-Sofia. 2021. Jonah through the Centuries. Wiley Blackwell Bible Commentaries. Malden: Blackwell.

Van Der Kolk, Bessel A. 2014. The Body Keeps the Score: Brain, Mind, and Body in the Healing of Trauma. New York: Viking.

Van Der Kolk, Bessel A., and Onno Van Der Hart. 1995. The Intrusive Past: The Flexibility of Memory and the Engraving of Trauma. In Trauma: Explorations in Memory. Edited by Cathy Caruth. Baltimore: John Hopkins University Press, pp. $158-82$.

Vickroy, Laurie. 2015. Reading Trauma Narratives: The Contemporary Novel and the Psychology of Oppression. Charlottesville: University of Virginia Press.

Walsh, Carey. 2015. The Metaprophetic God of Jonah. In History, Memory, Hebrew Scriptures: A Festschrift for Ehud Ben Zvi. Edited by Diane Gersoni-Edelman and Ian Douglas Wilson. Winona Lake: Eisenbrauns, pp. 259-74.

Wildberger, Hans. 1997. Isaiah 13-27: A Continental Commentary. Translated by Thomas H. Trapp. Minneapolis: Fortress.

Williams, Pip. 2021. The Dictionary of Lost Words. New York: Random House.

Yates, Gary. 2016. The 'Weeping Prophet' and 'Pouting Prophet' in Dialogue: Intertextual Connections between Jeremiah and Jonah. JETS 59: 223-39. 